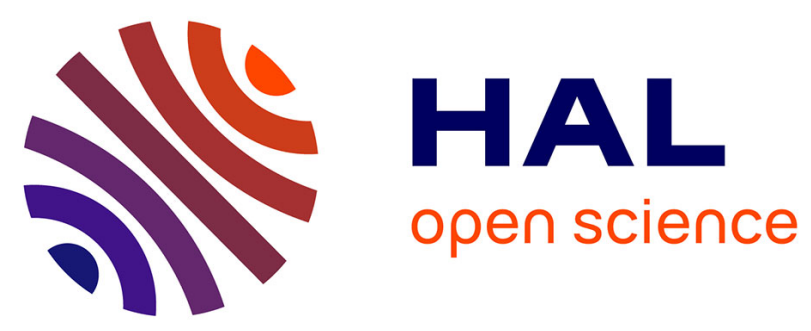

\title{
Comment on the article The Cambridge Structural Database in chemical education: analysis of hydrogen-bonded networks in salts of hexaaqua metal ions with organic counter-ions \\ Massimo Nespolo
}

\section{To cite this version:}

Massimo Nespolo. Comment on the article The Cambridge Structural Database in chemical education: analysis of hydrogen-bonded networks in salts of hexaaqua metal ions with organic counter-ions. Journal of Applied Crystallography, 2021, 54, pp.707 - 707. 10.1107/s1600576721001606 . hal03187420

\section{HAL Id: hal-03187420 \\ https://hal.univ-lorraine.fr/hal-03187420}

Submitted on 1 Apr 2021

HAL is a multi-disciplinary open access archive for the deposit and dissemination of scientific research documents, whether they are published or not. The documents may come from teaching and research institutions in France or abroad, or from public or private research centers.
L'archive ouverte pluridisciplinaire HAL, est destinée au dépôt et à la diffusion de documents scientifiques de niveau recherche, publiés ou non, émanant des établissements d'enseignement et de recherche français ou étrangers, des laboratoires publics ou privés. 


\title{
Comment on the article The Cambridge Structural Database in chemical education: analysis of hydrogen-bonded networks in salts of hexaaqua metal ions with organic counter-ions
}

\author{
Massimo Nespolo
}

J. Appl. Cryst. (2021). 54, 707

\section{-1U IUCr Journals CRYSTALLOGRAPHY JOURNALS ONLINE}

Author(s) of this article may load this reprint on their own web site or institutional repository provided that this cover page is retained. Republication of this article or its storage in electronic databases other than as specified above is not permitted without prior permission in writing from the IUCr.

For further information see https://journals.iucr.org/services/authorrights.html 
JOURNAL OF

APPLIED

CRYSTALLOGRAPHY

ISSN 1600-5767

Received 5 December 2020

Accepted 10 February 2021

Edited by K. Chapman, Stony Brook University, USA

Keywords: low-dimensional structures; subperiodic objects

\section{Comment on the article The Cambridge Structural Database in chemical education: analysis of hydrogen-bonded networks in salts of hexaaqua metal ions with organic counter-ions}

\author{
Massimo Nespolo*
}

Université de Lorraine, CRM2, UMR 7036, Nancy, France. *Correspondence e-mail: massimo.nespolo@univ-lorraine.fr

A recent article by Moret (2020) describes 'infinite 1D structures (linear or zigzag chains) and infinite 2D structures (layers)'. I have already pointed out several times the incorrectness of these expressions (Nespolo, 2019a,b), yet they still appear even in IUCr journals. It is clearly necessary to call for more attention from the authors of crystallographic manuscripts, to avoid these mistakes increasing misunderstandings among readers.

A 'low-dimensional' structure would be, by definition, a structure that can be embedded in a lower-dimensional space. Its symmetry would be represented by a line (one-dimensional space) or plane (two-dimensional space) group. The chains and layers which are the addressed by Moret (2020) are by no means one-dimensional or bidimensional, respectively, because they have finite nonzero width and cannot be embedded in a one-dimensional or bidimensional space. They are perfectly three-dimensional objects which, however, lack periodicity along two or one direction, respectively, of the space. Accordingly, their symmetry is described by a subperiodic group, namely a rod and a layer group, respectively. The correct way of referring to them is by the terms 'monoperiodic' and 'diperiodic', respectively. The importance of making clear this fundamental difference becomes even more evident by considering the limiting case of a nonperiodic object (a finite module). By keeping the incorrect wording 'low-dimensional', one would get a 'zero-dimensional' object. Table 1 compares the symmetry of low-dimensional objects (which are fictitious geometrical entities) and that of real subperiodic objects.

Subperiodic modules (bricks; rod or chains; sheets or layers) are the building blocks of modular structures. Modular crystallography was recognized as an important approach to the investigation of complex structures about a century ago (Umayahara \& Nespolo, 2020). It is today an extremely active field of research, in particular for crystal engineering, although not all authors realize that the building blocks they discuss, far from being conceptually new, are actually not different from the modules already addressed long ago. Calling these modules ' $0 \mathrm{D}, 1 \mathrm{D}, 2 \mathrm{D}$ structures' is a serious mistake that may potentially prevent investigators from realizing that a huge literature on how to deal with modular structures already exists. It is therefore of paramount importance to correct this improper notation to ' $0 \mathrm{P}, 1 \mathrm{P}, 2 \mathrm{P}$ structures', for nonperiodic, monoperiodic and diperiodic, respectively.

Table 1

Lower-dimensional (fictitious) versus subperiodic (real) objects and their symmetry groups.

\begin{tabular}{|c|c|c|c|}
\hline $\begin{array}{l}\text { Lower-dimensional } \\
\text { object }\end{array}$ & Symmetry group & $\begin{array}{l}\text { Subperiodic object } \\
\text { (module) }\end{array}$ & Symmetry group \\
\hline $\begin{array}{l}\text { OD: a dimensionless } \\
\text { point }\end{array}$ & $\begin{array}{l}\{1\} \text { (a point group containing } \\
\text { only the identity) }\end{array}$ & $\begin{array}{l}\text { OP: brick, polyhedron, } \\
\text { molecule ... }\end{array}$ & Point group \\
\hline 1D: line & Line groups (2 types) & 1P: chain, rod & Rod groups (75 types) \\
\hline 2D: plane & Plane groups (17 types) & 2P: sheet, layer & Layer groups (80 types) \\
\hline
\end{tabular}

\section{References}

Moret, M. (2020). J. Appl. Cryst. 53, 1593-1602.

Nespolo, M. (2019a). J. Appl. Cryst. 52, 451-456.

Nespolo, M. (2019b). IUCr Newsl. 27, 6.

Umayahara, A. \& Nespolo, M. (2020). Cryst. Res. Technol. 55, 1900045. 